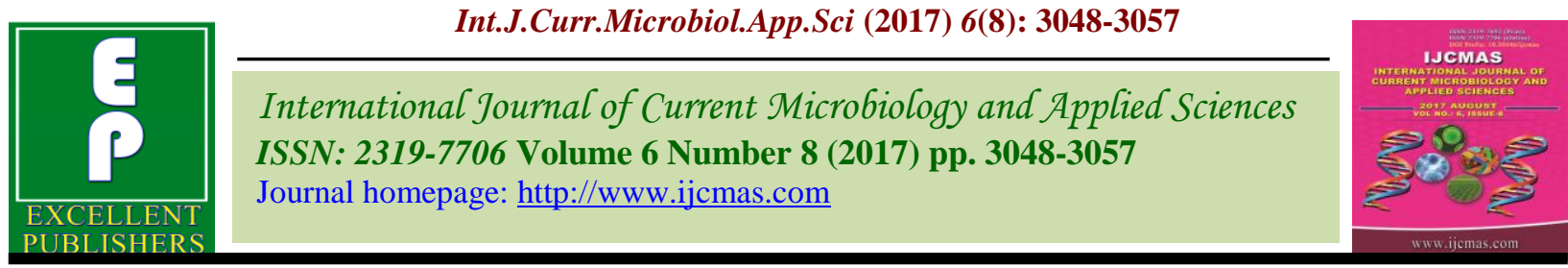

Original Research Article https://doi.org/10.20546/ijcmas.2017.608.364

\title{
Impact of Social Media upon Undergraduates Student Behaviors in University of Kufa, Iraq
}

\author{
Mansour Abdullah Falah ${ }^{1}$, Ahmed A. Al-Shammari ${ }^{2}$ and Ibrahim A.K. AL-Ashour ${ }^{1}$ \\ ${ }^{1}$ Department of nursing, Kufa University, Najaf, Iraq \\ ${ }^{2}$ Department Microbial Genetics, College of Biotechnology, \\ Al-Nahrain University, Baghdad, Iraq \\ *Corresponding author
}

\begin{abstract}
A B S T R A C T
There has been a great and rapid development in technology of various kinds, including social media, which have made the world a small village. In terms of

\section{Keywords}

Impact, Social

Media, Behaviors.

Article Info

Accepted:

23 June 2017

Available Online:

10 August 2017 video and audio communication, different behaviors have appeared in recent times, affecting the behavior of individuals negatively. A study of descriptive between Kufa University students for Day and Night studies was conducted for both sexes. A sample of (525) male and female students from all 21 university faculties was taken from 25 students randomly. Starting with the study from December 2016 to March 2017, a heterogeneous stratified sample was selected. The data was collected by means of a questionnaire designed and composed of three parts. The first part included the demographic information ( 5 items). The second part included information about social media that included (4 items) and last information about the behavior included (50 items). The study showed that $36 \%$ of the students were affected by the social media. As for the other demographic part, no significant relationship was found.
\end{abstract}

\section{Introduction}

Social media has exploded as a category of online discourse where people create content, share it, bookmark it and network at a prodigious rate. Because of its ease of use, speed and reach, social media is fast changing the public discourse in society and setting trends and agenda in topics that range from the environment and politics to technology and the entertainment industry (Asur, S., and Huberman, B.A., 2010). In the last ten years, the online world has changed dramatically, thanks to the invention of social media, young men and women now exchange ideas, feelings, personal information, pictures and video sat a truly astonishing rate.
Seventy-three percent of wired American teens now use social media websites (Oberst, 2010).

Martn, (2008) and Lusk, (2010) share the same concept of social media. To them social media is the use of Facebook, Blogs, Twitter, My Space and LinkedIn for the purpose of communication, sharing photos a swell as videos. However, for the purpose of this study social media is captured within the use of internet through Facebook, Whats App, Twitter, Skype, Myspace as well as Yahoo Messenger for communication sharing of ideas, sharing of photos and videos by users. 
The increased use of Social Networking Websites has become an international phenomenon in the past several years. What started out as a hobby for some computer literate people has become a social norm and way of life for people from all over the world (Boyd, D., 2010)?

Teenagers and young adults have especially embraced these sites as a way to connect with their peers, share information, reinvent their personalities, and showcase their social lives (Boyd, D., 2010).

In the past years, social media websites have become common; giving young people a new way to interact with each other and communicate with the world. Social networking became popular between 2004and 2006, after Facebook and Myspace were created. Facebook, for example has over 500 million members and it is still growing and approximately $85 \%$ of undergraduate students are Facebook users (Schneider N., 2010).

These numbers are expected to grow since Facebook users will continue to grow. And this is not only true for Facebook, numbers for YouTube users closely follow as well (University of New Hampshire, 2010).

The main objective of this study includes to assess the common social media used by students in universe of kufa. And to assess students in universe of kufa behaviors. Also to determine the impact of social Media (Internet include: (Twitter, Facebook, Instagram, YouTube), TV, and other) on first stage students in universe of kufa behaviors. This study also identify the relationship between social Media (Internet include: (Twitter, Facebook, Instagram, YouTube), $\mathrm{TV}$, and other) on first stage student's university and their socio-demographic characteristic.

\section{Design of study}

Cross section Descriptive study correlation analytic study was conducted to identify impact of social media on student's college behavior, including (525) student in university of kufa nursing faculty. (December 2016 to March 2017). A sample of (525) male and female students from all 21 universities faculties was taken from 25 students randomly.

\section{Administrative arrangement}

Prior to actual collection data, formal administrative approval was obtained to conduct the study from following: -

A- An official arrangement paper was obtained from the faculty of nursing.

\section{Setting of the study}

The study was conducted at the students of University of Kufa

\section{Sampling and sample selection}

Disproportional stratify sample technique was used, a purposive sample of (525) students of university of kufa.

\section{Methods of data collection and tools}

Data were collected through the use of questionnaire from data were collected in the following sequences: -

\section{Interviewing of study sample}

The investigator collected data from study by using an interviewing questionnaire form, the questionnaire included three parts: demographic data (5 items), social media data (4 items). Behavior data (50 items). 


\section{Statistically analysis}

A descriptive statistical method (parametric method for percentages, frequency and mean), and inferential statistical method (chi-square, correlation coefficient and $\mathrm{P}$ value) were used to analyze the data.

\section{Results and Discussion}

This chapter presents the findings of the data analysis systematically in tables as they correspond with the objectives of the study as follows:

A methodically arranged understanding and rationally derived discussion of study results will be presented in this chapter with the support of the available literatures and related studies. The data were analyzed through the application of descriptive and inferential statistics in order to meet the study objectives. The majority ages of the students are (17-21) years old (89.3\%), and the common of them are female $(52.8 \%)$. In edition of the students are urban residence and accounts (85.5\%). In satisfied economic states (45.6\%). Also the majority of students are single (93.5\%).

The table 6 shows that the cell phone is the dominant social media tools that used by student $(89.5 \%)$ but the smart watch is the Mainer tools used by the student (98.9\%).

Table 1 presents that the Facebook is the most common social media program used by the students $(86.1 \%)$.

But the Emo is fewer common social media program used by the students (5.3\%).

Fig.1 The observed frequencies and percentages of subjects' groups according to sociodemographic data

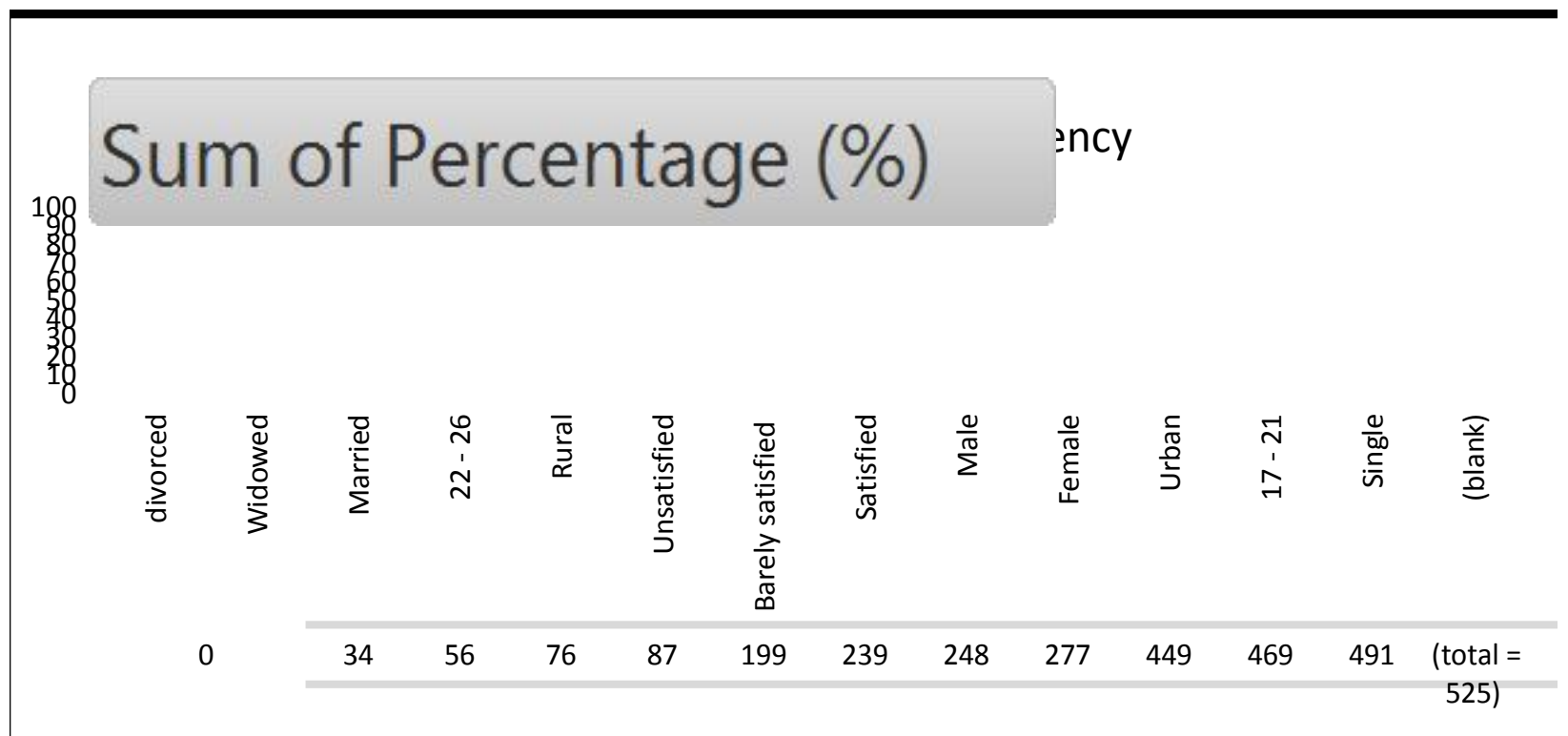

This figure shows that the majority of age the students are (17-21) years old $(89.3 \%)$, and the majority of them are female $(52.8 \%)$. In edition of the students are urban residence and accounts $(85.5 \%)$. In satisfied economic states (45.6\%). Also the majority of students are single (93.5\%).

Fig.2 Descriptive of study sample according to the used of social media tools 


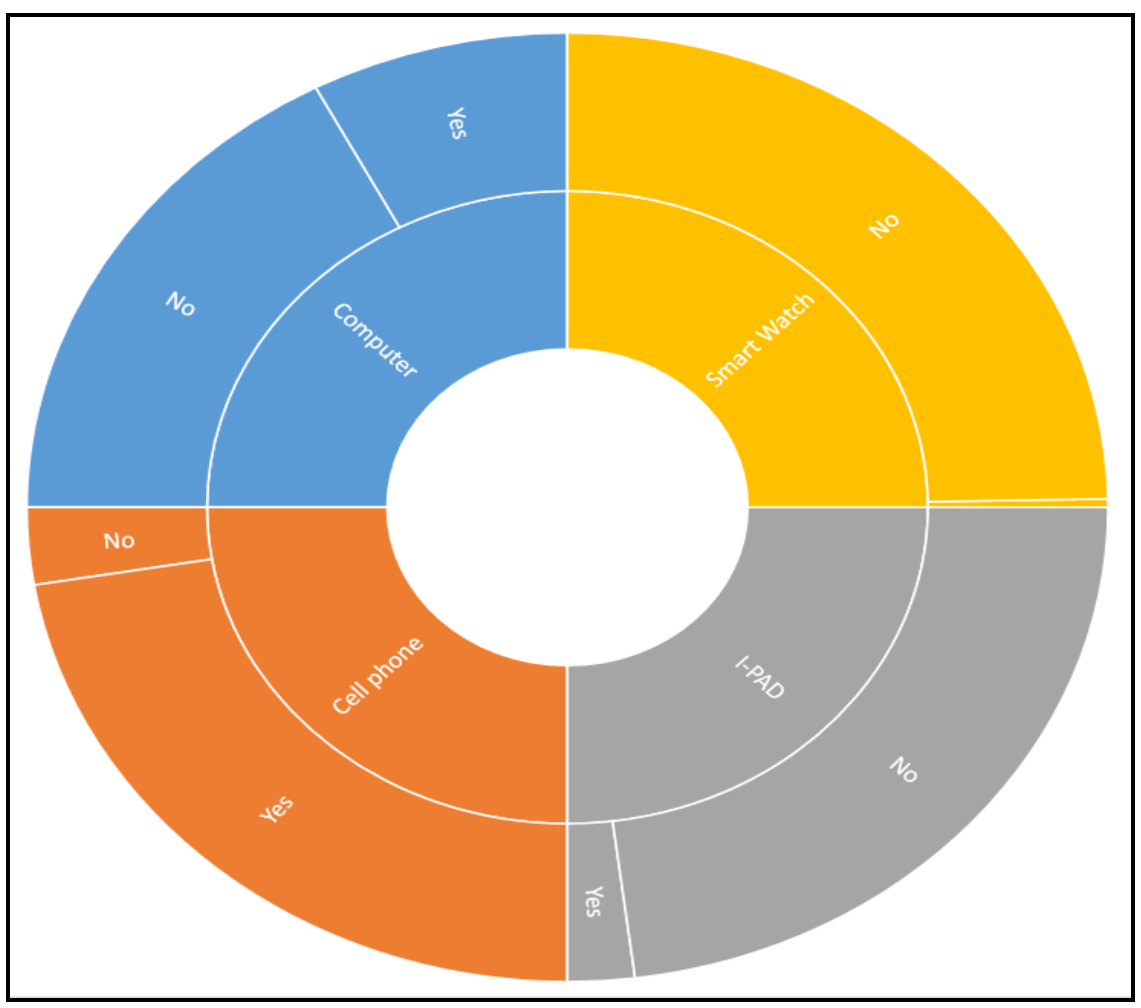

This figure shows that the cell phone is the dominant social media tools that used by student (89. 5\%). while the smart watch is the Mainer tools used by the student (98.9\%).

Table.1 Descriptive of study sample according to the used of social media programs

\begin{tabular}{|l|l|l|l|}
\hline Description of biological hazards & Items & Freq. & Percentage \\
\hline \multirow{2}{*}{ Facebook } & Yes & $\mathbf{4 5 2}$ & $\mathbf{8 6 . 1}$ \\
\cline { 2 - 4 } & No & $\mathbf{7 3}$ & $\mathbf{1 3 . 9}$ \\
\hline \multirow{2}{*}{ Instagram } & Yes & $\mathbf{2 2 0}$ & $\mathbf{4 1 . 9}$ \\
\cline { 2 - 4 } & No & $\mathbf{3 0 5}$ & $\mathbf{5 8 . 1}$ \\
\hline \multirow{2}{*}{ YouTube } & Yes & $\mathbf{3 0 3}$ & $\mathbf{5 7 . 7}$ \\
\cline { 2 - 4 } & No & $\mathbf{2 2 2}$ & $\mathbf{4 2 . 3}$ \\
\hline \multirow{2}{*}{ What's Up } & Yes & $\mathbf{1 9 5}$ & $\mathbf{3 7 . 1}$ \\
\cline { 2 - 4 } & No & $\mathbf{3 3 0}$ & $\mathbf{6 2 . 9}$ \\
\hline \multirow{2}{*}{ Viber } & Yes & $\mathbf{3 0 3}$ & $\mathbf{5 7 . 7}$ \\
\hline \multirow{2}{*}{ Emo } & No & $\mathbf{2 2 2}$ & $\mathbf{4 2 . 3}$ \\
\hline \multirow{2}{*}{ Messenger } & Yes & $\mathbf{2 8}$ & $\mathbf{5 . 3}$ \\
\cline { 2 - 4 } & No & $\mathbf{4 9 7}$ & $\mathbf{9 4 . 7}$ \\
\hline \multirow{2}{*}{ Twitter } & Yes & $\mathbf{3 6 4}$ & $\mathbf{6 9 . 3}$ \\
\cline { 2 - 4 } & No & $\mathbf{1 6 1}$ & $\mathbf{3 0 . 7}$ \\
\hline
\end{tabular}

This table shows that the Facebook is the most common social media program used by the students $(86.1 \%)$. While the Emo is less common social media program used by the students (5.3\%). 
Table.2 Descriptive statistics of assessment for how to use social media

\begin{tabular}{|l|l|l|l|}
\hline Description of biological hazards & Items & Freq. & Percentage \\
\hline \hline \multirow{3}{*}{ Use of social networks } & Daily & 441 & $\mathbf{8 4 . 0}$ \\
\cline { 2 - 4 } & Weekly & 63 & $\mathbf{1 2 . 0}$ \\
\cline { 2 - 4 } time of networks using & Monthly & $\mathbf{2 1}$ & $\mathbf{4 . 0}$ \\
\hline \multirow{3}{*}{ hours of networks using } & night & 157 & $\mathbf{2 9 . 9}$ \\
\cline { 2 - 4 } & day & 47 & $\mathbf{9 . 0}$ \\
\cline { 2 - 4 } & All the time & $\mathbf{3 1 9}$ & $\mathbf{6 0 . 8}$ \\
\hline & $\mathbf{1 - 5}$ & $\mathbf{3 9 3}$ & $\mathbf{7 4 . 9}$ \\
\hline & $\mathbf{6 - 1 0}$ & $\mathbf{9 7}$ & $\mathbf{1 8 . 5}$ \\
\hline
\end{tabular}

This table shows that the majority of study sample use of social networks Daily and accounts for (84.0\%) in the study sample, and the majority of them used of social media all the time and accounts for (60.8\%). The majority of the students used social media for (1-5) hours daily are accounts for (74.9\%).

Table.3 The observed frequencies and percentages and assessment of Students' social behavior

\begin{tabular}{|c|c|c|c|c|c|c|}
\hline No. & Items & & $\begin{array}{l}\text { Freq. } \\
\text { (total } \\
525)\end{array}$ & Percentage & MS & Ass. \\
\hline \multirow[t]{3}{*}{1.} & \multirow{3}{*}{$\begin{array}{l}\text { Do you ignore the views and } \\
\text { opinions of others view }\end{array}$} & always & 32 & 5.9 & \multirow{3}{*}{2.19} & \multirow[t]{3}{*}{ pass } \\
\hline & & Sometimes & 363 & 69.3 & & \\
\hline & & Never & 130 & 24.8 & & \\
\hline \multirow[t]{3}{*}{2.} & \multirow{3}{*}{$\begin{array}{l}\text { Do you become prone to screech or } \\
\text { a target for immediate anger by } \\
\text { others? }\end{array}$} & always & 35 & 6.7 & \multirow[b]{3}{*}{2.41} & \multirow[t]{3}{*}{ pass } \\
\hline & & Sometimes & 240 & 45.7 & & \\
\hline & & Never & 250 & 47.6 & & \\
\hline \multirow[t]{3}{*}{3.} & \multirow{3}{*}{$\begin{array}{l}\text { Do you publish rumors and gossip } \\
\text { from others }\end{array}$} & always & 15 & 2.9 & \multirow{3}{*}{2.80} & \multirow[t]{3}{*}{ pass } \\
\hline & & Sometimes & 76 & 14.5 & & \\
\hline & & Never & 434 & 82.7 & & \\
\hline \multirow[t]{3}{*}{4.} & \multirow{3}{*}{ Are the accusations directed to others } & always & 22 & 4.2 & \multirow{3}{*}{2.64} & \multirow[t]{3}{*}{ pass } \\
\hline & & Sometimes & 144 & 27.4 & & \\
\hline & & Never & 359 & 68.4 & & \\
\hline \multirow[t]{3}{*}{5.} & \multirow{3}{*}{$\begin{array}{l}\text { Does the intimidating behavior, such } \\
\text { as pointing the finger towards others }\end{array}$} & always & 28 & 5.3 & \multirow{3}{*}{2.64} & \multirow[t]{3}{*}{ pass } \\
\hline & & Sometimes & 134 & 25.5 & & \\
\hline & & Never & 363 & 69.1 & & \\
\hline \multirow[t]{3}{*}{6.} & \multirow[t]{3}{*}{ Do you intrude on others } & always & 15 & 2.9 & \multirow{3}{*}{2.71} & \multirow[t]{3}{*}{ pass } \\
\hline & & Sometimes & 124 & 23.6 & & \\
\hline & & Never & 386 & 73.5 & & \\
\hline \multirow[t]{3}{*}{7.} & \multirow[t]{3}{*}{ Do you work on teasing others } & always & 29 & 5.5 & \multirow{3}{*}{2.57} & \multirow[t]{3}{*}{ pass } \\
\hline & & Sometimes & 166 & 31.6 & & \\
\hline & & Never & 330 & 62.9 & & \\
\hline \multirow[t]{3}{*}{8.} & \multirow{3}{*}{$\begin{array}{l}\text { Are you a permanent harness } \\
\text { excessively from others }\end{array}$} & always & 23 & 4.4 & \multirow{3}{*}{2.67} & \multirow[t]{3}{*}{ pass } \\
\hline & & Sometimes & 127 & 24.2 & & \\
\hline & & Never & 375 & 71.4 & & \\
\hline 9. & Are you suggesting, or refer others to & always & 23 & 4.4 & & pass \\
\hline & force them to leave the place & Sometimes & 180 & 34.3 & 2.57 & \\
\hline & & Never & 322 & 61.3 & & \\
\hline
\end{tabular}




\begin{tabular}{|c|c|c|c|c|c|c|}
\hline \multirow[t]{3}{*}{10.} & \multirow{3}{*}{$\begin{array}{l}\text { Is exposed to others ridiculous jokes } \\
\text { to people you do not deal with them. }\end{array}$} & always & 31 & 5.9 & \multirow{3}{*}{2.61} & \multirow[t]{3}{*}{ pass } \\
\hline & & Sometimes & 144 & 27.4 & & \\
\hline & & Never & 350 & 66.7 & & \\
\hline \multirow[t]{3}{*}{11.} & \multirow{3}{*}{$\begin{array}{l}\text { Do you can focus on your actions in } \\
\text { everything you do }\end{array}$} & always & 47 & 8.6 & \multirow{3}{*}{2.45} & \multirow[t]{3}{*}{ pass } \\
\hline & & Sometimes & 257 & 49.1 & & \\
\hline & & Never & 221 & 42.3 & & \\
\hline \multirow[t]{3}{*}{12.} & \multirow{3}{*}{$\begin{array}{l}\text { Do you feel like you're playing a } \\
\text { useful role in matters }\end{array}$} & always & 88 & 16.8 & \multirow{3}{*}{2.15} & \multirow[t]{3}{*}{ pass } \\
\hline & & Sometimes & 272 & 51.8 & & \\
\hline & & Never & 165 & 31.4 & & \\
\hline \multirow[t]{3}{*}{13.} & \multirow{3}{*}{$\begin{array}{l}\text { Do you feel you are capable of } \\
\text { decisions taken in your affairs }\end{array}$} & always & 137 & 26.1 & \multirow{3}{*}{1.92} & \multirow[t]{3}{*}{ Fail } \\
\hline & & Sometimes & 292 & 55.6 & & \\
\hline & & Never & 96 & 18.3 & & \\
\hline \multirow[t]{3}{*}{14.} & \multirow{3}{*}{$\begin{array}{l}\text { Do you feel you are under the } \\
\text { influence of the constant stress }\end{array}$} & always & 96 & 18.3 & \multirow{3}{*}{2.00} & \multirow[t]{3}{*}{ pass } \\
\hline & & Sometimes & 331 & 63.0 & & \\
\hline & & Never & 98 & 18.7 & & \\
\hline \multirow[t]{3}{*}{15.} & Do you feel not being able to & always & 61 & 11.6 & & pass \\
\hline & overcome your difficulties & Sometimes & 161 & 30.7 & 2.46 & \\
\hline & & Never & 303 & 57.7 & & \\
\hline 16. & Do you feel that life is a continuous & always & 255 & 9.9 & & Fail \\
\hline & Jihad and suffering & Sometimes & 218 & 41.5 & 1.61 & \\
\hline & & Never & 52 & 48.6 & & \\
\hline No. & Items & & $\begin{array}{l}\text { Freq. } \\
\text { (total } \\
525 \text { ) }\end{array}$ & Percentage & MS & Ass. \\
\hline 17. & & always & 209 & 39.8 & 178 & Fail \\
\hline & Do you feel happy in your activities & Sometimes & 225 & 42.9 & 1.78 & \\
\hline & & Never & 91 & 17.3 & & \\
\hline 18. & & always & 233 & 44.4 & & Fail \\
\hline & Do you treat things seriously & Sometimes & 226 & 43.0 & 1.68 & \\
\hline & & Never & 66 & 12.6 & & \\
\hline 19. & & always & 247 & 47.0 & 165 & Fail \\
\hline & Do you feel the fear and norror of & Sometimes & 216 & 41.1 & 1.63 & \\
\hline & & Never & 62 & 11.8 & & \\
\hline 20. & & always & 246 & 46.9 & & Fail \\
\hline & Can you face your problems & Sometimes & 236 & 45.0 & 1.61 & \\
\hline & & Never & 43 & 8.2 & & \\
\hline 21. & Do you feel that things are not & always & 100 & 19.0 & & pass \\
\hline & beside you & Sometimes & 279 & 53.1 & 2.09 & \\
\hline & & Never & 146 & 27.8 & & \\
\hline 22. & Do you feel no joy & always & 51 & 33.6 & & Fail \\
\hline & & Sometimes & 298 & 56.9 & 1.76 & \\
\hline & & Never & 176 & 9.5 & & \\
\hline 23. & Do not feel self confidence & always & 233 & 44.4 & 166 & Fail \\
\hline & & Sometimes & 239 & 45.5 & 1.66 & \\
\hline & & Never & 53 & 10.1 & & \\
\hline 24. & Do you think the person you are & always & 119 & 22.7 & & Fail \\
\hline & interest-free & Sometimes & 307 & 58.5 & 1.96 & \\
\hline & & Never & 99 & 18.9 & & \\
\hline 25. & Do you feel that life is not hopeless & always & 98 & 18.7 & 100 & Fail \\
\hline & & Sometimes & 340 & 64.8 & 1.98 & \\
\hline & & Never & 87 & 16.6 & & \\
\hline
\end{tabular}




\begin{tabular}{|c|c|c|c|c|c|c|}
\hline \multirow[t]{3}{*}{26.} & \multirow[t]{3}{*}{ Do you feel hope for the future } & always & 175 & 33.3 & \multirow{3}{*}{1.80} & \multirow[t]{3}{*}{ Fail } \\
\hline & & Sometimes & 278 & 53.0 & & \\
\hline & & Never & 72 & 13.7 & & \\
\hline \multirow[t]{3}{*}{27.} & \multirow{3}{*}{$\begin{array}{l}\text { Do you feel you are on the whole } \\
\text { satisfied }\end{array}$} & always & 161 & 30.7 & \multirow{3}{*}{1.80} & \multirow[t]{3}{*}{ Fail } \\
\hline & & Sometimes & 308 & 58.7 & & \\
\hline & & Never & 56 & 10.7 & & \\
\hline \multirow[t]{3}{*}{28.} & \multirow{3}{*}{$\begin{array}{l}\text { Do you feel the emotion and tension } \\
\text { all the time }\end{array}$} & always & 211 & 40.2 & \multirow{3}{*}{1.71} & \multirow[t]{3}{*}{ Fail } \\
\hline & & Sometimes & 253 & 48.2 & & \\
\hline & & Never & 61 & 11.6 & & \\
\hline \multirow[t]{3}{*}{29.} & \multirow{3}{*}{$\begin{array}{l}\text { Do you feel that life is not worth } \\
\text { living }\end{array}$} & always & 139 & 26.5 & \multirow{3}{*}{2.02} & \multirow[t]{3}{*}{ pass } \\
\hline & & Sometimes & 237 & 45.1 & & \\
\hline & & Never & 149 & 28.4 & & \\
\hline \multirow[t]{3}{*}{30.} & \multirow{3}{*}{$\begin{array}{l}\text { Do you find that you sometimes } \\
\text { cannot do any work, because your } \\
\text { temper tired }\end{array}$} & always & 197 & 37.5 & \multirow{3}{*}{1.75} & \multirow[t]{3}{*}{ Fail } \\
\hline & & Sometimes & 263 & 50.1 & & \\
\hline & & Never & 65 & 12.4 & & \\
\hline \multirow[t]{3}{*}{31.} & Do Tell your sleep due to the & always & 89 & 17.0 & 204 & pass \\
\hline & excessive use of smart devices & Sometimes & 324 & 61.7 & 2.04 & \\
\hline & & Never & 112 & 21.3 & & \\
\hline 32. & Do you suffer from the disorder and & always & 84 & 16.0 & 210 & pass \\
\hline & discomfort at night & Sometimes & 306 & 58.3 & 2.10 & \\
\hline & & Never & 135 & 25.7 & & \\
\hline 33. & Are you able to keep distracting & always & 60 & 11.4 & & pass \\
\hline & yourself & Sometimes & 190 & 36.2 & 2.41 & \\
\hline & & Never & 275 & 52.4 & & \\
\hline No. & Items & & $\begin{array}{l}\text { Freq. } \\
\text { (total } \\
525 \text { ) }\end{array}$ & Percentage & MS & Ass \\
\hline 34. & & always & 85 & 16.2 & & pass \\
\hline & Do you go out of the house without & Sometimes & 209 & 39.8 & 2.46 & \\
\hline & & Never & 231 & 44.0 & & \\
\hline 35. & & always & 272 & 51.8 & & pass \\
\hline & Are you able to manage your alrairs & Sometimes & 186 & 35.4 & 2.28 & \\
\hline & & Never & 67 & 12.8 & & \\
\hline 36. & Are you caticfied with what they & always & 138 & 26.3 & & Fail \\
\hline & Are you satisned with what they & Sometimes & 313 & 59.6 & 1.61 & \\
\hline & & Never & 74 & 14.1 & & \\
\hline 37. & Do you feel satisfied with your & always & 75 & 14.3 & & Fail \\
\hline & achievement in a way for your & Sometimes & 310 & 59.0 & 1.88 & \\
\hline & business & Never & 140 & 26.7 & & \\
\hline 38. & Do you feel warm emotion towards & always & 65 & 12.4 & & pass \\
\hline & those who are close to you & Sometimes & 287 & 54.8 & 2.12 & \\
\hline & & Never & 172 & 32.8 & & \\
\hline 39. & Do you find it easy adopted with & always & 106 & 20.2 & & pass \\
\hline & others & Sometimes & 311 & 59.2 & 2.20 & \\
\hline & & Never & 108 & 20.6 & & \\
\hline 40. & Do you spend a lot of time ensuring & always & 164 & 31.2 & & pass \\
\hline & with others you & Sometimes & 227 & 43.2 & 2.00 & \\
\hline & & Never & 134 & 25.5 & & \\
\hline 41. & You got problems as a result of the & always & 65 & 12.4 & & Fail \\
\hline & use of social media & Sometimes & 230 & 43.8 & 1.94 & \\
\hline & & Never & 230 & 43.8 & & \\
\hline
\end{tabular}




\begin{tabular}{|c|c|c|c|c|c|c|}
\hline \multirow[t]{3}{*}{42.} & \multirow{3}{*}{$\begin{array}{l}\text { Do gained friends through social } \\
\text { media }\end{array}$} & always & 78 & 14.9 & \multirow{3}{*}{2.31} & \multirow[t]{3}{*}{ pass } \\
\hline & & Sometimes & 193 & 36.8 & & \\
\hline & & Never & 254 & 48.4 & & \\
\hline \multirow[t]{3}{*}{43.} & \multirow{3}{*}{$\begin{array}{l}\text { Has there been a change in behavior } \\
\text { as a result of the use of social media }\end{array}$} & always & 67 & 12.8 & \multirow{3}{*}{2.34} & \multirow[t]{3}{*}{ pass } \\
\hline & & Sometimes & 211 & 40.2 & & \\
\hline & & Never & 247 & 47.0 & & \\
\hline \multirow[t]{3}{*}{44.} & \multirow{3}{*}{$\begin{array}{l}\text { Did you see or imitate all you read } \\
\text { in the media of social } \\
\text { communication }\end{array}$} & always & 120 & 22.9 & \multirow{3}{*}{2.34} & \multirow[t]{3}{*}{ pass } \\
\hline & & Sometimes & 274 & 52.2 & & \\
\hline & & Never & 131 & 25.0 & & \\
\hline \multirow[t]{3}{*}{45.} & \multirow{3}{*}{$\begin{array}{l}\text { Has there been an improvement in } \\
\text { your behavior when you use social } \\
\text { media }\end{array}$} & always & 123 & 23.4 & \multirow{3}{*}{2.02} & \multirow[t]{3}{*}{ pass } \\
\hline & & Sometimes & 293 & 55.8 & & \\
\hline & & Never & 109 & 20.8 & & \\
\hline \multirow[t]{3}{*}{46.} & \multirow{3}{*}{$\begin{array}{l}\text { Do you encourage others to use } \\
\text { social media }\end{array}$} & always & 88 & 16.8 & \multirow{3}{*}{1.97} & \multirow[t]{3}{*}{ Fail } \\
\hline & & Sometimes & 293 & 55.8 & & \\
\hline & & Never & 144 & 27.4 & & \\
\hline \multirow[t]{3}{*}{47.} & \multirow{3}{*}{$\begin{array}{l}\text { Do you consider social media a } \\
\text { waste of time }\end{array}$} & always & 82 & 15.6 & \multirow{3}{*}{2.11} & \multirow[t]{3}{*}{ pass } \\
\hline & & Sometimes & 227 & 43.3 & & \\
\hline & & Never & 215 & 41.0 & & \\
\hline \multirow[t]{3}{*}{48.} & \multirow{3}{*}{$\begin{array}{l}\text { Are my observations are affected by } \\
\text { violence and the risk presented by } \\
\text { these networks }\end{array}$} & always & 77 & 14.7 & \multirow{3}{*}{2.25} & \multirow[t]{3}{*}{ pass } \\
\hline & & Sometimes & 229 & 43.6 & & \\
\hline & & Never & 219 & 41.7 & & \\
\hline \multirow[t]{3}{*}{49.} & \multirow{3}{*}{$\begin{array}{l}\text { Do you become } \\
\text { annihilated prevented } \\
\text { social media }\end{array}$} & always & 64 & 12.2 & \multirow{3}{*}{2.27} & \multirow[t]{3}{*}{ pass } \\
\hline & & Sometimes & 251 & 47.9 & & \\
\hline & & Never & 209 & 39.9 & & \\
\hline 50. & Do you use social media make you & always & 85 & 16.2 & & pass \\
\hline & isolated from your friends and your & Sometimes & 209 & 39.8 & & \\
\hline & family & Never & 231 & 44.0 & 2.28 & \\
\hline
\end{tabular}

Cutoff point $=2$; pass $>=2$; fail $<2$

This table shows that assessment of student's behavior is pass at all items, except at items numbers $(13,16,17,18,19,20,22,23,24,25,26,27,28,30,36,37,41$ and 47$)$ their behavior is fail that means that $36 \%$ of the students present with negative affected behavior.

Table.4 Overall assessment of student' social behavior

\begin{tabular}{|l|l|l|l|}
\hline Questions No. $=\mathbf{5 0}$ & MS & R.S. \% & Assess. \\
\hline \hline Total Behavior Domain & 2.13 & 71 & Moderate affected \\
\hline
\end{tabular}

m.s (2), cut off point (0.66), poor (m. $\mathrm{s}=1-1.66)$ moderate (1.76-2.33), good behavior (2.34 and more)

This table shows that the overall assessment of the student's behavior moderately affected due to using of social media.

Table.5 Relationship between students' socio-demographic data and their social behavior

\begin{tabular}{|l|c|c|c|}
\hline Groups & Chi-Square & P-value & Sig. \\
\hline Age (years) & 1.00 & .6067 & NS \\
\hline Gender & .74 & .3903 & NS \\
\hline Residence & .03 & .8669 & NS \\
\hline Monthly income & .17 & .9195 & NS \\
\hline Marital status & .13 & .7222 & NS \\
\hline
\end{tabular}

This table present Relationship between students' socio-demographic data and their social behavior, there are no significance. 
Table.6 Relationship between students' using of social media and their social behavior

\begin{tabular}{|l|c|c|c|}
\hline Description of biological hazards & Chi-Square & P-value & Sig. \\
\hline \hline Computer & .00 & .9901 & NS \\
\hline Cell phone & .35 & .5552 & NS \\
\hline I-PAD & .47 & .4920 & NS \\
\hline Smart Watch & .75 & .3855 & NS \\
\hline Facebook & 1.54 & .2151 & NS \\
\hline Instagram & .80 & .3701 & NS \\
\hline YouTube & 1.40 & .2372 & NS \\
\hline What's Up & .73 & .3919 & NS \\
\hline Viber & 1.38 & .2395 & NS \\
\hline Emo & .00 & .9527 & NS \\
\hline Messenger & 1.20 & .2725 & NS \\
\hline Twitter & .00 & .9723 & NS \\
\hline Use of social networks & 2.91 & .0878 & NS \\
\hline hours of networks using & .25 & .8845 & NS \\
\hline Time of networks using & .06 & .8122 & NS \\
\hline
\end{tabular}

This table present Relationship between students' using of social media and their social behavior, there are no significance.

The table 2 shows that the common of study sample use of social networks Daily and accounts for $(84.0 \%)$ in the study sample, and the majority of them used of social media all the time and accounts for $(60.8 \%)$. The majority of the students used social media for (1-5) hours daily are accounts for (74.9\%).

The table 4 shows that assessment of student's behavior is majority is pass at all items, except fewer items the behavior is fail that means that $36 \%$ of the students present with negative affected behavior (7).

A study conducted by (7) showed that the impact of social networking sites on the behavior of university students.

The table 6 shows that the overall assessment of the student's behavior moderately affected due to using of social media (Table 3).

The table 5 present Relationship between students' socio-demographic data and their social behavior, there are no significance.
According to the present study findings, we can make the following conclusions:

The results of the study showed an average effect on the behavior of students through the use of social media. And was more mobile in the use of social media and especially Facebook, and was used at all times daily and at a rate of 1-5 hours a day. And there is no relationship between behavior and demographic information (age, residency, gender, monthly income, marital status).

\section{Recommendation}

Determining the time required for schools and not being overly preoccupied with the use of social media.

Conduct similar studies on different communities, including the community, children and students of basic school stages, and examine the impact of using sites Social Media. 
Raising awareness among young people about the role and impact of social media in the development of their personalities and guide them to the optimal use of social networking sites.

The need to hold training courses for young people aimed at developing their skills in the recruitment of sites Social communication in the service of their issues and the issues of their nation, especially in the field of advocacy and pressure.

Focusing on school and university students through awareness-raising through posters and posters Purpose.

Call for the establishment of youth groups targeted on the site of social communication, which adopts social and cultural issues to exchange knowledge and spread the benefit.

\section{References}

Asur, S., and Huberman, B.A. 2010. Predicting the Future with Social Media. Social Computing Lab: HP Labs, Palo Alto, California. pp 1- 8.

Boyd, D., 2010. Taken Out of Context:
American Teen Sociality in Networked Publics Berkeley, CA: University of California; 2008. at:www.danah.org/papers/TakenOutOf Context.pdf. Accessed July 16, 2010 Domine, V., 2009. A social history of media, technology and schooling. Journal of Media Literacy Education, 1(1), 42-52.

Kalpidou, M., Costin, D., \& Morris, J. 2011. The relationship between Facebook and the well-being of undergraduate college students. Cyberpsychology, Behavior \& Social Networking, 14 (4), 183-189.

Oberst, L., 2010. The 6S Social Network. Retrieved from: http://six sentences.ning.com/profile/Lin dsayOberst.

Schneider N., 2010. Facebook, Other Social Network Sites Could Lead to Lower Grades for Students.http://www.associatedcontent. com/article.1650000/facebook_other social_network_sites.html. Retrieved 2017/08/13

University of New Hampshire, 2010. Student Grades Not Affected by Social Networkinghttp://www.newswise.com/a rticles/student-grades-not-affected-bysocial-networking new-research-finds. Retrieved 20/08/13

\section{How to cite this article:}

Mansour Abdullah Falah, Ahmed A. Al-Shammari and Ibrahim A.K. AL-Ashour. 2017. Impact of Social Media upon Undergraduates Student Behaviors in University of Kufa. Int.J.Curr.Microbiol.App.Sci. 6(8): 3048-3057. doi: https://doi.org/10.20546/ijcmas.2017.608.364 